\title{
Discussing immigration in an illiberal media environment: Hungarian political scientists about the migration crisis in online public discourses
}

\section{Eszter Farkas ${ }^{1,2}$}

Accepted: 16 March 2021

(c) European Consortium for Political Research 2021

\begin{abstract}
Despite the fact that Hungary was less affected by the 2015 migration crisis in objective terms - i.e. the negligible number of immigrants entering and settling in the country in the last years-, the Hungarian government has been pushing an extreme anti-immigration political communication since 2015, which resulted in an intensive and highly politicised public discourse about immigration. This analysis aims at exploring the involvement of political scientists in the online public discourse about the migration and refugee crisis in Hungary between 2015 and 2019. In contrast with other countries, where high salient political crises have stimulated political scientists' public engagement, this analysis finds that such participation does not apply to the Hungarian case. The low visibility of political scientists is accompanied by the adoption among participants in news portals of either a partisan, pro-government stance or a neutral approach to the issue, while critical positions with the government are almost inexistent. These patterns suggest the influence of both the illiberal institutional turn of the Hungarian media environment and the decrease in academic freedom in the country, as factors deterring public engagement among political scientists in the immigration issue, particularly of those who could adopt a critical position.
\end{abstract}

Keywords Discourse analysis · Hungary · Migration crisis · Political scientists · PROSEPS survey

Eszter Farkas

farkas_eszter@phd.ceu.edu

1 Doctoral School of Political Science, Central European University, Nador u. 9, Budapest 1051, Hungary

2 Institute for Political Science, Centre for Social Sciences, Tóth Kálmán u. 4., Budapest 1097, Hungary 


\section{Introduction}

After 2015, migration has become the most heated policy issue in Hungarian public and media discourses. The influx of immigrants during the summer of 2015 meant a significant external shock for Hungarian citizens and political actors, and resulted in a politicised political and media discourse (see e.g. Boros 2019). The Hungarian government especially enforced this discourse: the anti-immigration rhetoric became the leading campaign communication frame of Fidesz and Viktor Orbán since the beginning of the crisis. Fidesz effectively internalized immigration as one of the main policy issues of Hungary during several electoral campaigns (Bíró-Nagy 2021). Public discourses of this tense nature, public salience and high politicisation should effectively stimulate political scientists to "put in their two cents" in the debate, as well, to demonstrate the social impact and relevance of related scientific knowledge. However, this analysis finds an extremely low rate of political scientists' contribution compared to the online media discourse's intensity.

This analysis aims at exploring the involvement of political scientists in the public discourse about the migration and refugee crisis in Hungary between 2015 and 2019, the framing of their contribution in online news portals. More specifically, I investigate political scientists' contributions to the immigration debate along three dimensions: (1) the degree of partisanship, (2) visibility of these contributions and (3) impact (though this later aspect is only dealt with as a side effect of the other two) (see Real-Dato and Verzichelli in this issue).

The Hungarian case offers the opportunity to analyse to what extent an illiberal political context may influence patterns of participation of political scientists in the public arena. Compared with other articles in this special issue also focusing on countries, which question liberal democracy, like Israel (Neubauer, 2021), illiberal tendencies have been more accentuated in Hungary. Since 2010, the politicisation of the media system under the dominance of the Hungarian government and the recent decrease in academic freedom might have affected political scientists' involvement in the public sphere (Bátorfy and Urbán 2020; Bárd 2020).

Hypothetically, both factors would act as external conditioning constraints deterring political scientists from engaging in public debates outside the academic environment. In this respect, we could expect reluctance of many academic political scientists to participate in this politicised context, either because they reject being tagged as partisan (particularly in the case of those individuals more committed to academic norms of neutrality and rigour) or, more importantly, because they fear that any critical involvement might have negative effects on their academic careers. In contrast with this dominant invisibility, we could also hypothesize that those participating refuse to criticize the government, by either adopting a neutral approach or aligning with pro-governmental positions.

This paper has the following structure. First, I present survey data on the limited participation of Hungarian political scientists in the public sphere, and link it to the political and media context. This section also highlights the signs of 
decreasing academic freedom, which most probably creates further burdens for political scientists to contribute to public debates. Second, I briefly describe the main features of the migration crisis in Hungary their framing ub the governmental and media discourses. A systematic discourse analysis of articles written by Hungarian political scientists in mainstream pro-government and independent online news portals follows. Besides embedding the Hungarian case within the other analyses of this special issue, the concluding section ascertains the generally low level of visibility and impact of political scientists in an illiberal media environment with decreasing academic freedom, and highlights the politicised manner of government-supportive political scientists in the public discussion about immigration.

\section{Hungarian political scientists in public debates}

A recent comparative survey carried out by the PROSEPS project ${ }^{1}$ has shown that Hungarian political scientists seem less committed to public debates compared to their European colleagues. Only 30\% of Hungarian respondents reported about taking part in public debates in the media in the last three years, which is significantly lower than the $57.5 \%$ rate in the total average. ${ }^{2}$ The intensity of engagement and contribution of political scientists is also lower than that of the European average. While general response patterns suggested a small but active minority within political scientists, $50 \%$ of those Hungarians who contributed to public debates in the last three years indicated the average frequency of their interventions as less frequently than yearly.

Two types of conditions could explain these patterns of reduced participation among Hungarian political scientists. First, internal conditions, like interiorized norms, according to which political scientists aim to maintain their expert position and avoid normative engagement in debates. Second, predisposition to contribute to public discourses in front of a wider audience stimulated by institutional (career) incentives. In the case of Hungary, the first factor seems to play an important role, since every political scientist that declared to have participated in public debates agreed (somewhat or fully) that this was part of their professional role (see Table 1). In contrast, career incentives seem to be much less important.

However, the importance of internal factors on Hungarian political scientists' participation in the public sphere does not seem to differ significantly from the whole PROSEPS sample, which reports higher levels of participation in the public sphere. This implies that low levels of participation in Hungary may depend on a

\footnotetext{
1 Professionalization and Social Impact of European Political Science (PROSEPS) (http://proseps.unibo. it/, accessed 20/02/2021). The PROSEPS online survey was carried out between May and December 2018 among a population of 11,012 academic political scientists in 37 European countries plus Israel and Turkey. The total number of respondents was 2354. The total number of Hungarian respondents was 66, which is $2.8 \%$ of the sample. [for further information see Vicentini et al. (2019)].

${ }^{2}$ In the other countries analysed in this special issue, these percentages are: Finland, 62.9; Greece, 61.5; Israel, 58.5; Italy, 58.8; Poland, 48.8; Spain, 53.6; United Kingdom, 60.1.
} 


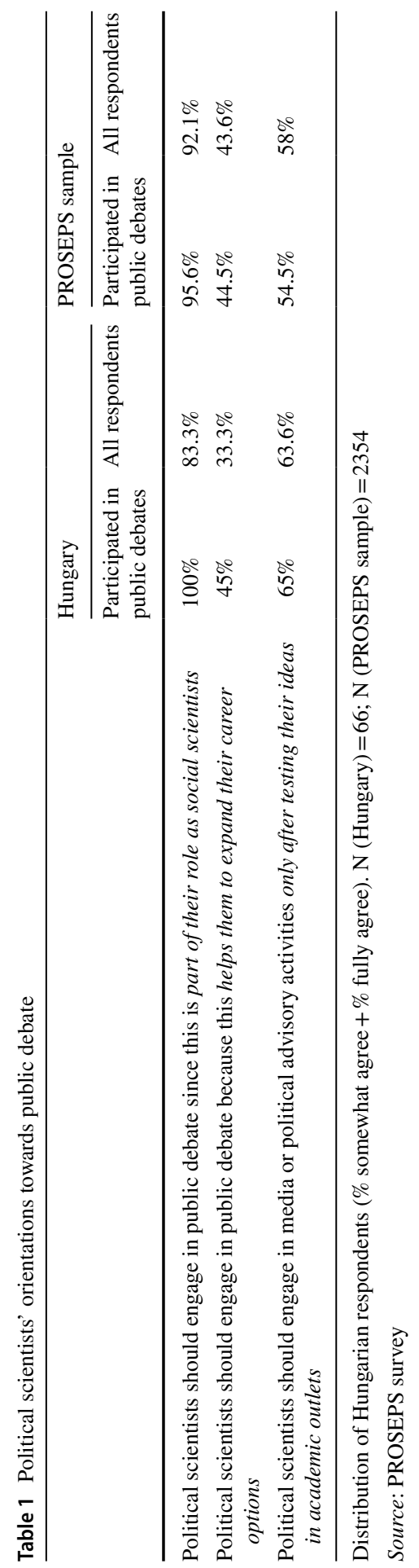

斿 
second set of factors - namely, external factors (Real-Dato et al. 2021). The political conditions established by the Fidesz government since its absolute majority in 2010 could have discouraged many Hungarian political scientists from participating in the public domain.

On the one hand, the weakening of liberal institutions has negatively affected the country's media plurality (Bátorfy and Urbán 2020). Bajomi-Lázár (2013) describes this process as the de-consolidation of the media freedom, during which new media regulation was introduced in order to suppress critical voices, gain favourable coverage and extract various media resources (p. 84).

Besides, in the last years, Hungarian academics have witnessed how the government has increased pressures aimed at restricting academic freedom (Enyedi 2018; Bárd 2020). For instance, in 2017 the government passed a higher education law (its popular name is "lex CEU") within a week, which unofficially aimed at hindering the operation of the Central European University, forcing this high-ranked international university to replace its main campus from Budapest to Vienna. Furthermore, the institutional changes and the financial cuts in the Hungarian Academy of Sciences have slowly transfered independence and decision-making rights to institutions that are loyal to the government (Scheiring 2019). As a symbolic attack against scientists and free academic work in 2018, an article in pro-government Figyelő magazine listed the names of researchers whose research topics regarded as "politically suspicious" and suggested greater insight from the government's side to the work of the Academy (Zubascu 2018). These uncertain conditions also contribute to the risks political scientists undertake when they take part in any public debates, which might result in limited access to state research funds or the uncertainty of their academic position. Hence, the illiberal turn in Hungarian politics has created an environment, which is not appropriate to stimulate participation in public debates, particularly for those scholars whose opinions are critical with the government, even if they do not adopt a partisan approach. ${ }^{3}$ In the rest of the article, I use the case of the migration crisis affecting several European countries since 2015 to explore the effects of the illiberal turn of the Hungarian government on the participation of political scientists in the online public sphere. More specifically, I will analyse such engagement across the three basic dimensions of public relevance: visibility, partisanship, and impact (Real-Dato et al. 2021).

\section{The migration crisis in Hungary}

The consequences of the influx of immigrants after the Syrian war and NorthAfrican revolutions caused a domestic political crisis in many European countries. However, the valence of these crises varied. Most affected countries were either bordering countries (Italy or Greece) or those, which were destination

\footnotetext{
3 In this respect, the PROSEPS data show that Hungary is not the only country where illiberal politics could negatively influence public engagement among political scientists: respondents in Turkey or Poland also experience lower levels of public engagement.
} 


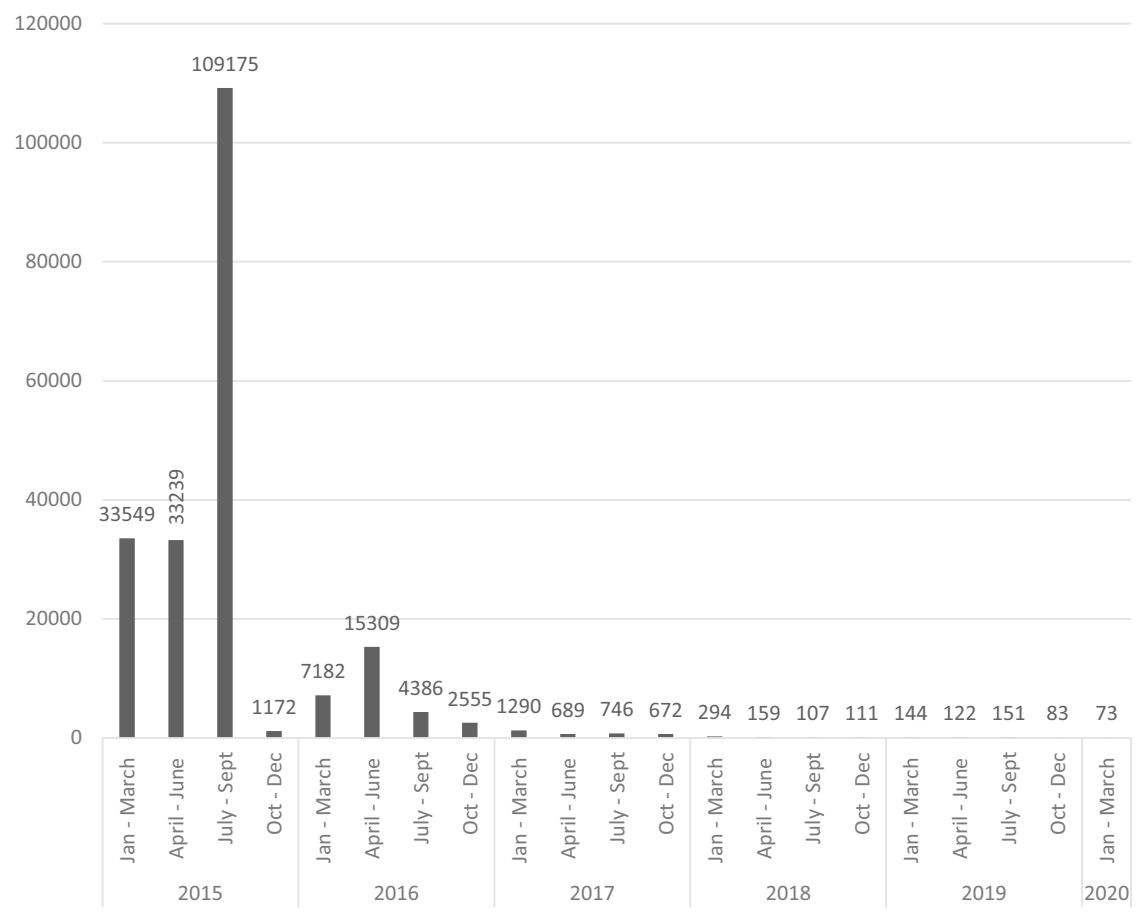

Fig. 1 The number of asylum seekers in Hungary 2015-2020. Source: Hungarian Central Statistical Office. Available at https://www.ksh.hu/docs/hun/xstadat/xstadat_evkozi/e_wnvn001.html, accessed 13 March, 2020

countries for refugees and immigrants (like Germany or Scandinavia). In Hungary, although the number of asylum seekers increased dramatically at the peak of the migration crisis in 2015, as soon as Angela Merkel declared the "Willkommenspolitik" of Germany in August 2015, the number of refugees asking for asylum in Hungary declined sharply (see Fig. 1).

As in other countries, the 2015 migration crisis generated in Hungary an extensive public debate, especially because Prime Minister Viktor Orbán and the governing party Fidesz have taken a clear anti-immigration position, using the counter-narrative to non-European immigrants as the main campaign message to mobilize their voters (Boros 2019; Glied and Pap 2016; Metz 2017). The government's political communication successfully expropriated the immigration issue gaining media attention and agenda-setting priorities from the previously far-right party Jobbik (Kiss and Szabó 2018). They spent an enormous amount of public money to disseminate their anti-immigration messages on posters, in various offline and online media outlets (Bernát and Messing 2015). According to the Hungarian government's position, Muslim immigrants are a serious threat to the security, economy, and Christian culture of Hungary, and "the government will counteract to protect Hungarian people from these threats". Several 
events extended the intensity of the discourse about immigration, like building the southern border barrier in 2015 or holding a referendum about refusing the EU's migration quota in October 2016 (Várnagy 2017). Though the mobilisation potential remained below the expected level and the referendum was invalid due to the low electoral turnout, the government's anti-immigration campaign was very intensive (Boda and Szabó 2017).

Despite the significant decrease in the number of asylum seekers after September 2015, the issue has still occupied a significant part of the Hungarian public discourse, and it became extremely politicised (Bernát and Messing 2015; Sik and Simonovits, 2019; Barna and Koltai 2019). The escalation of the political debate about the migration crisis in Hungary resulted in the increase of government's support. The majority of Hungarian citizens follow anti-immigration attitudes (Messing and Ságvári 2019; Bíró-Nagy 2021), and several studies showed a tight correlation between being a Fidesz supporter and opposing immigrants from non-European countries to enter the continent and Hungary (Barna and Koltai 2019). The migration crisis became a key topic of Prime Minister Viktor Orbán and the governing party Fidesz to such an extent that the intensive anti-immigration communication helped Fidesz to regain its popularity after a sharp decline in 2014. The anti-immigration message successfully became the leading political issue (or rather concern) especially among government supporters, and dominated the public discourse even at the 2018 national election and 2019 European Parliamentary election campaigns (Bíró-Nagy 2021).

The Hungarian government has constantly framed the issue as a crisis and a threat towards the Hungarian society in general and declared an emergency in this regard in 2016 that has been in force since then. ${ }^{4}$ The government linked the the issue of immigration with different forms of threats that immigrants impose to the Hungarian society, creating the securitisation dimension of the debate (Glied and Pap 2016). Immigration remained the most important political concern of Hungarian people even years after the waves of immigrants arrived and were present in the country. It even appeared during the 2019 municipal election campaign, when the government still frequently enhanced the migration danger in their everyday communication. ${ }^{5}$

Opposition political actors are careful about expressing their policy position in this regard because it is difficult to address any inclusive political messages in an environment characterised by mainly anti-immigration attitudes. Although there are some opposition politicians who explicitly support integrative attitude toward immigrants, Hungarian opposition parties' communication do not emphasize these positions, simply because their voters also do not necessarily support the idea of

\footnotetext{
4 The crisis situation is officially in force since 2016 and has been consequently renewed every six months. See the related 41/2016. government decree: https://net.jogtar.hu/jogszabaly?docid=a1600041. kor, accessed 13 March 2020.

5 As a typical example, the mayor of the Northern Hungarian village Salgótarján was accused of installing new public wells especially for immigrants, where the chance of their appearance is almost zero. Source: Index (2019). Fidesz candidate: are wells built for migrants? Available at https://index.hu/belfo 1d/2019/10/01/salgotarjan_ivokut_migransok_fekete_sandor_fenyvesi_gabor accessed 13 March 2020.
} 
an inclusive society (Boros 2019). Consequently, critical voices are rather absent in the public discourse compared to the intensity of the government's anti-immigration messages.

\section{Methodology: selection of articles and the logic of discourse analysis}

For the selection of relevant articles, I need to first specify who is a political scientist. To keep in line with the PROSEPS project, I included political scientists who (1) worked at universities in political science departments, or (2) in the Institute for Political Science at the Hungarian Academy of Sciences, or (3) in private research institutes or think tanks that focus on topics related to politics. This resulted in a list of 127 political scientists in Hungary, among which 88 (70\%) were employed at universities, 39 (31\%) worked at the Academy, and 29 (23\%) in research institutes. Positions can overlap, which means that more than one institution can employ political scientists. Academic employees are more likely to fulfil more than one position, than those who work at research institutes.

Second, I need to justify the selection of media sources. The structure and logic of the Hungarian media system fits into the process of Hungary becoming an "illiberal state" or "hybrid regime", where most of the democratic institutions are transformed into undemocratic state organisations. For example, Bozóki and Hegedús (2018) argue that "since the unilateral modifications of the constitution in 2013 (...) or the 2014 unfair elections at the latest, the Hungarian political system belongs in the category of non-democratic regimes" (p. 3). The two-third majority of the Fidesz-KDNP government in the national parliament since 2010 allows them to complete structural changes in public institutions, including the media. Pro-government oligarchies bought a significant rate of ownership in national media holdings, and thus gained important decision-making rights for media content (Bátorfy and Urbán 2020).

The analysis focuses on online media sources exclusively. Although television channels are still the most popular sources of news consumption, because of the unbalanced media ownerships in favour of government-friendly businesspersons, there is a lack of access for many political scientist experts to most television channels. Thus, the appearance of political scientists who are critical with the government is exceptionally low there. From a practical point of view, systematic data collection of television programs across years can be especially complicated.

A relative balance in media coverage is a feature of the online media space, where independent news portals are competitive in reaching the same number of daily visitors as government supportive news sources. Therefore, I included in the empirical analysis the most popular online portals financed, maintained, and edited by government-supportive public and economic figures, and the most popular liberalleft-wing news portals, who are financially independent from the government, and where the dominant tone of articles is often critical with the Hungarian government. The two pro-government news portals included in the analysis are mno.hu (Magyar 
Nemzet) and magyaridok.hu (Magyar Idôk). ${ }^{6}$ The selected independent news portals are index.hu, 444.hu, 24.hu. ${ }^{7}$ Search strings for the selection of immigration related articles used for the scraping process are in "Appendix".

Concerning the time frame of the study, it would have been reasonable to narrow down the analysis to the peak of the migration crisis in Hungary (that is approximately between the summer of 2015 and the migration referendum in October 2016), when the debate was the most intensive and thus the most frequent contributions of political scientists were to expect. However, considering the long-lasting presence of immigration in the political communication of the government (Boros 2019; Bíró-Nagy 2021) and looking at the exact distribution of articles, only half of political scientists' articles were written during the most intensive period of the immigration crisis. Consequently, the issue of immigration was persistent not only in the government's communication, but obviously in experts' interpretation as well. Therefore, I extended the analysis from January 2015 until September 2019 to show that the politicised topic of immigration remained in the public discussion and to see, at what stages of this debate the contribution of political scientists was the most intensive.

As the result of web-scraping the number of articles related to immigration is enormous (in the six sources there were altogether 61,443 articles, reports, opinion pieces about immigration during these four years). However, political scientists wrote less than 1\%, all of which are opinion pieces (Fig. 2). This is the reason why in the empirical analysis I mostly rely on a comprehensive qualitative discourse analysis of contributions along the key theoretical dimensions defined by the interpretative framework (visibility, partisanship and impact). As suggested by Gordon (2015), discourse analysis considers the key research questions and processes the articles by structuring their content along the aspects of the analysis.

The basic analytical dimensions considered in the qualitative content analysis is partisanship. I add a second dimension, visibility, in the next section, separately, using a simple analysis of frequencies of participation across different media. Finally, I assess the the impact of the interventions of Hungarian political scientists in the immigration debate in the concluding section, following the analysis of the

\footnotetext{
${ }^{6}$ During the investigated period, there was a change in ownership of Magyar Idôk and Magyar Nemzet. Although Magyar Idők was a pro-government media outlet, because of a change in ownership, the journal ceased to exist on 5 February 2019, and continued to operate under the name of Magyar Nemzet. Magyar Nemzet represented a sort-of opposition voice until this change. Magyar Nemzet is a special case among Hungarian media sources because of the change in the newspaper's ownership and the turn of its political position that followed afterwards. The newspaper was a loyal media towards Fidesz and Prime Minister Viktor Orbán until the so-called "G-day" on February 6 2015. The "G-day" represented the escalation of fights between Viktor Orbán and his formerly tight friend, Lajos Simicska, owner of the media outlet. After this turn, Magyar Nemzet became critical of the Fidesz government. Following the third electoral victory of Fidesz on April 11 2018, the newspaper officially ceased to exist. Since February 2019, Magyar Nemzet has functioned as the successor of government-friendly Magyar Idők and took the name of the former newspaper.

7 Another popular government-friendly news portal is origo.hu, however, since it publishes anonymous articles only, the detection of political scientists' contributions was not possible in that case. Although the reference to political scientists' in the articles could have been a specific type of contribution as well, the almost 8000 articles about immigration do not contain any of such references.
} 
30000

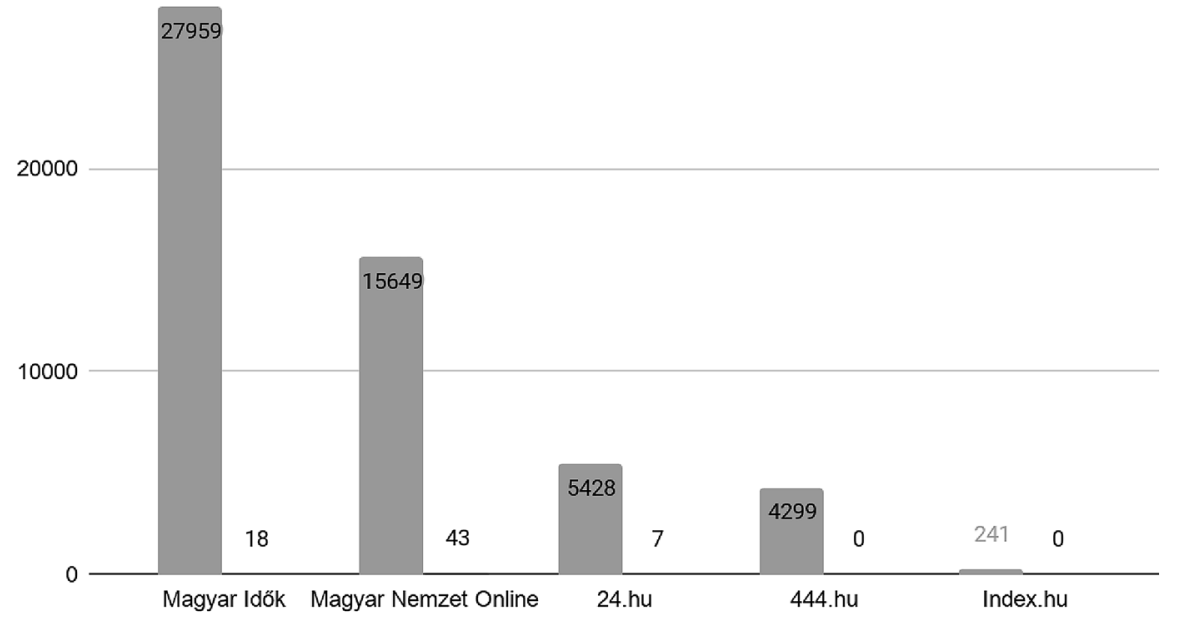

Fig. 2 Number of articles about the migration crisis between 2015 and 2019 in the online news portals selected in the analysis. Source: author's compilation

other two dimensions. Regarding partisanship and impact, I focus on (1) whether articles contain any explicit political position (in support or opposition with the government), and (2) the intention and ability of these articles to influence policymakers' decisions. In addition, I use framing analysis (Pan and Kosicki 1993) to compare how the article presents the issue to readers in both politicised and not politicised articles. With this, I aim at providing a more nuanced idea about how the politicisation of the immigration issue tries to shape the policy debate and the reader's mind (Lakoff 1996). I will add several quotations to support the qualitative discourse analysis.

\section{Lack of visibility-the frequency of political scientists' contributions in media sources}

The frequency of articles about the migration crisis in the investigated news portals clearly shows the difference in how much emphasis pro-government and independent news portals put on the migration crisis. The prevalence of articles on immigration is significantly higher in government-friendly media than in independent news portals-see article frequencies in Fig. 2.

Although the number of articles in the news portals about migrants, immigrants and refugees was enormous during the investigated period, political scientists contributed very rarely, especially in independent media sources, where these kinds of reflections are almost non-existent. Moreover, the distribution of contributions does not follow the intensity of the migration debate across time; the frequency does not 
Table 2 Number of immigration related articles written by political scientists, and the number of political scientists publishing any related articles per outlet

$\begin{array}{ll}\begin{array}{l}\text { Number of articles written by politi- } \\ \text { cal scientists }\end{array} & \begin{array}{l}\text { Number of political } \\ \text { scientists publishing any } \\ \text { articles }\end{array}\end{array}$

\begin{tabular}{lrr}
\hline Magyar Idők & 18 & 5 \\
Magyar Nemzet Online & 43 & 11 \\
24.hu & 7 & 3 \\
\hline
\end{tabular}

Source: author's compilation

increase during the inflow of immigrants in the summer of 2015 or the referendum about the migration quota held in October 2016.

Figure 2 shows that, overall, the proportion of pieces written by political scientists remains below $1 \%$ in every media outlet. Overall, the total number of participants were 17, out of a population of 127 (about $15 \%$, see Table 2 ). ${ }^{8}$ Besides, and in line with the findings of the PROSEPS survey about the uneven distribution of participation in the public sphere (Real-Dato et al. 2021), each Hungarian political scientist participating in the migration debate published an average of 3.5 articles between 2015 and 2019.

Most political scientists published in pro-governmental news portals (Table 2). In fact, the news portal 24.hu is the only independent portal where some political scientists reflected on the discourse about immigration. Neither index.hu, nor 444. hu published any analysis written by political scientists or referred to any political scientists' work or statement.

As for the affiliations of those participating, about $70 \%$ of contributing political scientists worked for private research institutions or think tanks, whereas opinion pieces from individuals who had working contracts with universities or the Academy were less frequent, 6 out of 17 contributing political scientists. Again, the overlapping positions mean that political scientists usually possess more than one affiliation, which is most typically a mixture of the academia and university. This different degree of activity between types of organisations resonates with a universal perception of political scientists' roles. While research institutions or think tanks usually offer support for certain political groups, employees of universities or the Academy prefer to maintain their independent and neutral roles, and thus are less likely to engage in public debates where normative standpoints are expressed. But, most importantly, differences in participation across types of organisations also strongly suggest how governmental financial and institutional rearrangements affecting universities and the Academy, aimed at curtailing academic freedom, might have acted as a deterrent of participation among political scientists affiliated to these institutions.

\footnotetext{
8 Two authors published in more than one outlet.
} 
Table 3 The rate of explicit political positions in the analyzed articles

\begin{tabular}{|c|c|c|c|c|}
\hline & \multicolumn{2}{|c|}{ Explicit political position } & \multirow[t]{2}{*}{ Neutral } & \multirow[t]{2}{*}{ Total } \\
\hline & $\begin{array}{l}\text { Supports the gov- } \\
\text { ernment }\end{array}$ & $\begin{array}{l}\text { Opposes the gov- } \\
\text { ernment }\end{array}$ & & \\
\hline Magyar Idők $(N=18)$ & $94 \%$ & $0 \%$ & $6 \%$ & $100 \%$ \\
\hline Magyar Nemzet Online $(N=43)$ & $30 \%$ & $2 \%$ & $68 \%$ & $100 \%$ \\
\hline 24.hu $(N=7)$ & $0 \%$ & $14 \%$ & $86 \%$ & $100 \%$ \\
\hline
\end{tabular}

In parentheses, the total number of articles written by political scientists at each outlet between 2015 and 2019

Source: author's compilation

Table 4 The rate of politicized and neutral articles across affiliations

\begin{tabular}{lll}
\hline \multicolumn{1}{c}{ Politicized } & Neutral & $\begin{array}{l}\text { Total by } \\
\text { affilia- } \\
\text { tions }\end{array}$ \\
\hline $\begin{array}{l}\text { Academy }+ \text { universi- } 0 \% \\
\text { ties }(N=10)\end{array}$ & $100 \%$ & $100 \%$ \\
$\begin{array}{l}\text { Research institutions } 48 \% \\
(N=58)\end{array}$ & $52 \%$ & $100 \%$ \\
\hline
\end{tabular}

In parentheses, the total number of articles produced by political scientists working at any type of institution

Source: author's compilation

\section{Results of the discourse analysis}

In this section, I first analyse the discourse in the articles produced by political scientists in terms of their partisan content and academic style. In a second subsection, I focus on the influence of partisanship in the use of different discursive frames.

\section{Partisanship and academic style}

Tables 3, 4 and 5 offer a quantitative synthesis of the results of the discourse analysis. Table 3 represents the percentage of articles adopting an explicit political position, Table 4 provides the same classification across affiliations. Therefore, the level of politicization can be inferred regarding media outlets and affiliations as well.

In terms of the politicisation of interventions, the corpus of articles analysed is divided in two halves, with $47 \%$ of the opinion pieces (32 in total) adopting a partisan stance. Therefore, in contrast with the results in other articles of this special issue, in Hungary, partisanship on the migration issue is more limited and, more interestingly, only expressed as support for the government. Therefore, of the 32 articles adopting partisan views, 30 (about 84\%) were pro-government, while only two expressed criticisms to how the Hungarian executive was managing the 


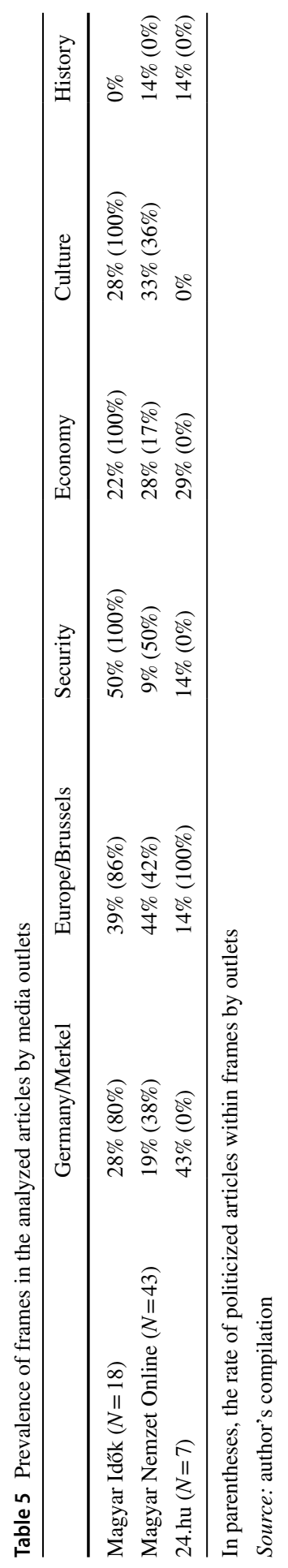


migration crisis. This finding constitutes additional evidence supporting the expectation that a hostile media environment for academics prevent them from taking critical positions.

When looking at the expression of partisanship, most of the articles in Magyar Idők clearly show support for the government. The use of several symbols drawn from the government's discourse, the regular accentuation of the policies and values represented by the government, and the obvious support of Viktor Orbán's leadership manifest this support. For example:

It was articulated many times before, that the migration crisis increased the role of Viktor Orbán from a regional to a European politician. His speech in Tusnádfürdő elevated him to a European reformer. ${ }^{9}$

Also, and similarly to the government's communication strategy, authors in these articles apply the common term "migrants" to immigrants, refugees and asylum seekers indistinctly. Besides, Brussels serves as reference to the whole European Union (EU) and its institutions, therefore presented as a centralised, bureaucratic entity (see below about the "Europe" frame):

Brussels supports Turkey's hospitality towards migrants with billions of euros yearly, which creates a stable and computable basis, but keeps the EU still in a blackmailed situation. ${ }^{10}$

The quota referendum has indeed effects on the European level, Brussels set back the pace. ${ }^{11}$

A recurrent element in these articles is also the relationship established between the migration issue and the suspected political intentions of György Soros, who the Hungarian government usually presents as the main enemy figure of the Hungarian nation:

György Soros gave political orders to Brussels in two main fields: they should maintain the common European currency, and boost the economy by allowing crowds of migrants to settle down in European countries. ${ }^{12}$

In Magyar Nemzet, there is a higher rate of alternation of various opinions (mostly neutral, but also pro-governmental and, to a lesser extent, critical), as well as a significantly higher level of academic style (Table 3). An explicit, pro-government political positioning is present in $30 \%$ of the articles. This positioning manifests itself in the use of similar elements as those outlined in case of Magyar Idő: supporting Viktor Orbán's policies and claims, using government-specific terms in

\footnotetext{
9 Magyaridok.hu (2017.a) Alternatíva Európa számára. Available at https://www.magyaridok.hu/velem eny/alternativa-europa-szamara-2013259/, accessed 13 March 2020.

10 Magyaridok.hu (2016.a) Soros az Európai Bizottság élén. Available at https://www.magyaridok.hu/ velemeny/soros-az-europai-bizottsag-elen-832216/, accessed 13 March 2020.

11 Magyaridok.hu (2017.c) Üzentünk Brüsszelnek. Available at https://www.magyaridok.hu/velemeny/ uzentunk-brusszelnek-1074478/, accessed 13 March 2020.

12 Magyaridok.hu (2016.b) Egy szoros összekötő kapocs. Available at https://www.magyaridok.hu/kulfo 1d/egy-szoros-osszekoto-kapocs-733813/, accessed 13 March 2020.
} 
the argumentation, or emphasising the anti-Hungarian intentions of György Soros. Moreover, several political scientists in Magyar Nemzet criticize the lack of clear immigration policy positions of left-wing opposition parties:

It is not about whether the left-wing-liberal political community would not have discussed these issues at all, but that they refused an open, comprehensive and conflict-loaded debate about migration. (...) for me it is not clear what opposition politicians think about the Dublin Regulation and about the continuous influx of crowds ${ }^{13}$

We still don't know how the "democratic opposition" would handle the situation if they governed. ${ }^{14}$

The few articles written by political scientists in the independent outlet 24 .hu are more likely to follow an academic style and adopt an observer position- the only article with a partisan stance criticizes that the Fidesz government neglects the consequences of climate change in terms of immigration:

(...) climate change will generate higher influxes of immigrants, which makes Orbán's message about handling the problems locally and not bringing migrants here, more difficult to maintain. ${ }^{15}$

Table 4 shows that all opinion pieces published by political scientists working at universities or the Academy follow a neutral tone, while among the contributions of political scientists working at research institutions, $48 \%$ use a politicized tone. These results reinforce the expectations outlined previously: first, political scientists that are supportive of the government are more likely to express normative political positions, whereas critical opinions towards the government are less likely to appear. Moreover, academic political scientists keep definite distance from participation, and communicate in a neutral tone.

\section{Partisanship and discursive frames}

In this subsection, I approach the following question: Does the explicit (pro-governmental) political position of an article influence how the authors frame the debate about immigration? I define frames a "journalistic professional routines and conventions" and therefore consider them as "a strategy of constructing and processing news discourse” (Pan and Kosicki 1993, p. 57). Table 5 summarizes the main frames appearing in the articles across outlets and indicates the rate of politicised articles

\footnotetext{
13 Magyarnemzet.hu (2016.c) A migráció és a balodal: igen vagy nem? Available at https://magyarnemz et.hu/archivum/velemeny-archivum/a-migracio-es-a-baloldal-igen-vagy-nem-3933270/, accessed 13 March 2020.

14 Magyarnemzet.hu (2016.d) Kollaboránsok a balodalon. Available at https://magyarnemzet.hu/archi vum/velemeny-archivum/kollaboransok-a-baloldalon-3932477/, accessed 13 March 2020.

15 24.hu (2019) Áder vírusként zöldíti a nemzetközi szervezeteket. Available at https://24.hu/belfold/ 2019/09/25/ader-janos-ensz-klimacsucs-2/, accessed 13 March 2020.
} 
within frames. Frame categories are not mutually exclusive, meaning that multiple frames might overlap in one article.

The "Europe/Brussels" frame situates the European Union as the core engine and main point of reference of the immigration issue. $40 \%$ of the articles use it in a highly politicised manner. They mostly appear in Magyar Nemzet and Magyar Idök. The prevalence of the European Union in these outlets is consistent with the Hungarian government's communication strategy focusing on blaming the EU (as well as other international forces) and holding it responsible for the immigration crisis. Besides, as a general tendency, politicised articles reference the EU by using the word "Brussels", or the German government by personalising chancellor Angela Merkel characterise. In articles that do not express any normative political positions, the "Europe" frame includes reflections about the relationship between liberal democracy and immigration and investigate how the tensions between these two realities affect positions of pro- and anti-immigration political groups.

The "Germany/Merkel" frames enhance the significant role of Germany and chancellor Angela Merkel in immigration policies and discuss further consequences, though these articles are less politicised. Interestingly, the "Germany" frame overwhelmingly appears in the articles of the independent 24.hu. Many arguments consider Angela Merkel's responsibility and significance in the current situation, several highlighting the contradicting attitudes towards Merkel's "Willkommenspolitik:

While those who criticize Merkel's politics regard the attitude of pro-integrative countries too soft and permissive, others who sympathize with Merkel's position see immigrants exclusively as vulnerable individuals, integrative countries strong and well organized. ${ }^{16}$

In contrast, in Magyar Nemzet and Magyar Idök, the "Germany" frame is much less frequent (appear in 19 and $28 \%$ of articles), and is less likely to be presented in a politicised style compared to the Europe/Brussels frame.

As the securitization literature suggest, the "security" frame interprets immigration as a source of threat on jobs, identities, or even lives of individuals (Szalai and Gőbl 2015). It appears abundantly in articles published in Magyar Idők, dominating the politicised pieces, and is much less frequent in the other two outlets. The arguments are usually in line with the government's political communication strategy:

[according to Brussels' liberal, hypocrite regulation of immigration] (...) illegal invaders cannot taken into custody, thus, before the Hungarian state could have defined their status and decide whether to allow them to stay or expel them $(\ldots)^{17}$

\footnotetext{
16 24.hu (2016) „,Angela Merkel a hibás, a törökök foglyai leszünk!. Available at https://24.hu/poszt-itt/ 2016/03/24/angela-merkel-a-hibas-a-torokok-foglyai-leszunk/, accessed 13 March 2020.

${ }^{17}$ Magyaridok.hu (2015) Bölcs és erôs magyar szuverenitásra van szükség. Available at https://www. magyaridok.hu/velemeny/bolcs-es-eros-magyar-szuverenitasra-van-szukseg-494197/, accessed 13 March 2020.
} 
The "cultural" frame underlines the cultural aspects of immigration, focusing on integration, multiculturalism, identities. This frame appears only in articles published in Magyar Nemzet (33\%) and Magyar Idök (28\%). Here there are differences between partisan and non-politicised articles. While the latter apply the "cultural" frame to discuss the several aspects and consequences of social integration of immigrants, pro-government articles emphasize the idea of multicultural society and criticise it. With respect to the "economy" frame, it appears in a significant portion of articles in all the outlets (from 22\% in Magyar Idők to $29 \%$ in 24.hu). This frame discusses the economic conditions and consequences of immigration. An important element is the argument of immigration as a source of positive economic externalities-i.e. immigrants as "cheap workforce". Such argument appears in several politicised and non-politicised analyses:

But to see further consequences of their cheapness, it is worth to declare direct numbers and rates: while immigrants are willing to work for 3-4 euros/hour, the average workforce expenditure in the EU is 25 euros/hour. ${ }^{18}$

As an extreme manifestation, pro-governmental versions of this frame accuse "the other" side of the political spectrum to expect migrants to become the basis of future economic growth:

(...) György Soros gave two political orders to Eurocrats in Brussels (...): to keep the unity of the European currency and to launch the economic growth by colonising the continent with immigrants! ${ }^{19}$

Finally, as an unusual element in the immigration debate, the "history" frame appears exclusively in non-politicised articles in Magyar Nemzet and 24.hu. These articles discuss important historical aspects and lessons about immigration:

This region never had colonies, the Hungarian society does not know much about how to behave with the suddenly appearing crowds. ${ }^{20}$

If we consider the various crises in the history of capitalist systems, it becomes evident that recessions were always followed by the conjecture of anti-immigration. $^{21}$

In sum, while typical frames to the migration debate appear in political scientists' interpretation as well, the applied frames and politicisation do not correlate. The politicised style of a contribution is more a result of the media outlet (progovernmental outlets are more likely to contribute in a politicised manner) or the

\footnotetext{
18 24.hu (2015.b) A menekülteket nem lehet Európa szélein letelepíteni, ôk a centrumba vágynak. Available at https://24.hu/belfold/2015/12/09/a-menekulteket-nem-lehet-europa-szelein-letelepiteni-ok-a-centr umba-vagynak/, accessed 13 March 2020.

19 Magyaridok.hu (2016.a) Soros az Európai Bizottság élén. Available at https://www.magyaridok.hu/ velemeny/soros-az-europai-bizottsag-elen-832216/, accessed 13 March 2020.

20 Magyarnemzet.hu (2016.f) A bevándorlás diskurzusa. Available at https://magyarnemzet.hu/archi vum/velemeny-archivum/a-bevandorlas-diskurzusa-3932862/, accessed 13 March 2020.

21 Magyarnemzet.hu (2016.g) A bevándorlásellenesség hullámai. Available at https://magyarnemzet.hu/ archivum/velemeny-archivum/a-bevandorlasellenesseg-hullamai-4252046/, accessed 13 March 2020.
} 
author's affiliation (political scientists at research institutions are more likely to publish politicised pieces).

\section{Concluding discussion}

In this article, I have systematically analysed the contributions of political scientists to the online public discourse about the migration crisis in Hungary, a highly salient and politicised issue since 2015. The peculiarity of the Hungarian case, compared to the other cases in this special issue, is that this debate took place in a political context characterised by an illiberal institutional turn in the Hungarian democratic system, and by a decline in academic freedom enforced by the government in the recent decade. Hence, the article has tried to show to what extent this hostile environment for academics has affected the participation of political scientists in the public sphere.

First, the data from the PROSEPS survey indicated that Hungarian political scientists (like their counterparts in Turkey and Poland, countries similarly affected by an illiberal turn) tend to participate in public debates significantly less than their colleagues in the rest of European countries. Second, among the few political scientists participating in the immigration debate, only a minority (6 people out of 17) worked at academic institutions (universities or the Academy of Sciences). This is also a remarkable contrast with other countries analysed in this issue, where academic political scientists populate more debates. The underrepresentation of this group in the case of Hungary is certainly another sign pointing to the deterring effect of the external pressures exerted on academics in this country over their predisposition to engage in public debates. Finally, the predominance of pro-governmental positions among those political scientists adopting a partisan stance is also a sign of this illiberal context. Such prevalence of a given opinion among political scientists adopting a partisan approach is not uncommon, as the articles in this special issue on Italy, United Kingdom or Greece demonstrate (in the latter case, such perception is biased by the selection effect of the TV media). However, in the case of Hungary, the context mentioned above (governmental control of the media, external pressures on academics) supports the idea that such predominance of pro-government views is not the result of a spontaneous general agreement within the political science community, but rather of a consensus created externally through the (self-)exclusion of critical voices.

In sum, and according to the three dimensions affecting the relevance of public engagement identified by Real-Dato et al. (2021), Hungarian political scientists have remained almost invisible, their impact is negligible, and they adopt a partisan position. In the end, the issue of migration in Hungary demonstrates the difficulties that nowadays political scientists (and other academics) find when trying to comply what Noam Chomsky (1967) termed as the responsibility of intellectuals "to speak the truth and to expose lies" of government to ordinary people. 


\section{Appendix: Hungarian and English search strings for article selection}

Strings referring to the migration crisis: 'határsértő' ('invader'), 'határsértés' ( 'invade'), 'bevándorló' ('immigrant'), 'bevándorlás', 'bevándorol', 'bevándorol' ('immigrate'), 'illegális+határátlépő' ('illegal+border crosser'), 'illegális+határátlépés' ('illegal+border crossing'), 'menedék' ('refuge'), 'menekül' ('escape'), 'menekült' ('refugee’), 'népvándorlás' ('migration'), 'népvándorló' ('migrating person'), 'oltalmazott' ('protected'), 'migráció' ('migration'), 'migrációs' ('related to migration'), 'migráns' ('migrant').

Acknowledgements I am grateful to Anna Székely for helping me with the data collection.

\section{References}

Bajomi-Lázár, P. 2013. The party colonisation of the media the case of Hungary. East European Politics and Societies 27 (01): 69-89.

Barna, I., and J. Koltai. 2019. Attitude changes towards Immigrants in the turbulent years of the "migrant crisis" and anti-immigrant campaign in Hungary. Intersections, East European Journal of Society and Politics 5 (1): 48-70.

Bárd, P. 2020. The rule of law and academic freedom or the lack of it in Hungary. European Political Science 19 (1): 89-96.

Bátorfy, A., and Á. Urbán. 2020. State advertising as an instrument of transformation of the media market in Hungary. East European Politics 36 (1): 44-65.

Bernát, G., and V. Messing. 2015. A menekültekkel kapcsolatos kormányzati kampány és a tôle független megszólalás terepei. Médiakutató 16 (4): 7-17.

Bíró-Nagy, A. 2021. Orbán's political jackpot: Migration and the Hungarian electorate. Journal of Ethnic and Migration Studies. https://doi.org/10.1080/1369183X.2020.18539051.

Boda, Zs., and A. Szabó. 2017. 'Mobilizáció és demobilizáció-tanulságok a menekültkvóta-népszavazás kapcsán. In Trendek a magyar politikában 2-A Fidesz és a többiek: pártok, mozgalmak, politikák, ed. Zs. Boda and A. Szabó, 249-281. Budapest: Napvilág Kiadó.

Boros, T. 2019. Hungary: A no-go zone for migrants. In European Public Opinion and Migration: Achieving Common Progressive Narratives, ed. Marco Funk, Hedwig Giusto, Timo Rinke, and Olaf Bruns. Berlin: Friedrich Ebert Stiftung.

Bozóki, A., and D. Hegedús. 2018. An externally constrained hybrid regime: Hungary in the European Union. Democratization 25 (7): 1173-1189.

Chomsky, N. 1967. 'The Responsibility of Intellectuals'. https://chomsky.info/19670223/. Accessed 11 October 2020 .

Enyedi, Zs. 2018. Democratic backsliding and academic freedom in Hungary. Perspectives on Politics 16 (4): 1067-1074.

Glied, V., and N. Pap. 2016. The 'Christian fortress of Hungary'-The anatomy of the migration crisis in Hungary. Yearbook of Polish European Studies 19: 133-150.

Gordon, C. 2015. Framing and positioning. In The handbook of discourse analysis, ed. D. Tannen, H.E. Hamilton, and D. Shiffrin, 324-345. Sussex: Wiley Blackwell.

Kiss, B., and G. Szabó. 2018. Constructing Political Leadership during the 2015 European migration crisis: The Hungarian case. Central European Journal of Communication 1: 9-24.

Lakoff, G. 1996. Moral politics: What conservatives know that liberals don't. Chicago: The University of Chicago Press.

Messing, V., and B. Ságvári. 2019. Still divided but more open. Mapping European attitudes towards migration before and after the migration crisis. Budapest: Friedrich Ebert Stiftung. 
Metz, R. 2017. Határok nélkül? Orbán Viktor és a migrációs válság. In Viharban kormányozni: Politikai vezetók válsághelyzetekben, ed. A. Körösényi, 240-264. Budapest: MTA Társadalomtudományi Kutatóközpont.

Pan, Z., and G.M. Kosicki. 1993. Framing analysis: An approach to news discourse. Political Communication 10 (1): 55-75.

Real-Dato, J., J. Rodríguez-Teruel, E. Martínez-Pastor, and E. Toledo-Estévez. 2021. The triumph of partisanship: political scientists in the public debate about Catalonia's independence crisis (20102018). European Political Science. https://doi.org/10.1057/s41304-021-00341-x.

Scheiring, G. 2019. Academic Freedom in Hungary's Authoritarian State Capitalism. https://fpc.org.uk/ academic-freedom-in-hungarys-authoritarian-state-capitalism/. Accessed 11 October 2020.

Szalai, A. and Gőbl, G. 2015. Securitizing migration in contemporary Hungary. Working Paper, Centre for European Neighbourhood Studies, Central European University. https://cens.ceu.edu/sites/cens. ceu.edu/files/attachment/event/573/szalaigoblmigrationpaper.final.pdf. Accessed 22 February 2021.

Várnagy, R. 2017. Hungary. European Journal of Political Research Political Data Yearbook 56: $123-128$.

Vicentini, Giulia, Jose Real Dato, Luca Verzichelli and Loannis Andreadis. 2019. Social Visibility and Impact of European Political Scientists. PROSEPS WG3 2019 Report. http://proseps.unibo.it/wpcontent/uploads/2019/10/WG3.pdf. Accessed 11 Oct 2020.

Zubascu, F. 2018. Orbán allies target Hungarian social scientists, in battle with Academy of Sciences. https://sciencebusiness.net/news/orban-allies-target-hungarian-social-scientists-battle-academysciences. Accessed 11 October 2020.

Publisher's Note Springer Nature remains neutral with regard to jurisdictional claims in published maps and institutional affiliations.

Eszter Farkas is currently a Phd candidate at the Doctoral School of Political Science at Central European University and a junior research fellow in Institute for Political Science, Centre for Social Sciences. Her doctoral research project focuses on media frames about immigration and the effects of these frames on public opinion and attitudes, comparing the cases of Hungary and Germany. Methodology of her research includes automated text analysis, survey data analysis, focus groups and survey experiments. 